\title{
The Humanities and Posthumanism
}

5

GRZEGORZ GROCHOWSKI

13

29

RYSZARD NYCZ

46

WLODZIMIERZ BOLECKI

53

64 OLGA CIELEMĘCKA

83 MAGDALENA POPIEL

112

PIOTR PIOTROWSKI

135

ARKADIUSZ ŻYCHLIŃSKI
Ubi Leones

Humanities: an Unfinished Project

Towards Innovative Humanities:

The Text as a Laboratory. Traditions,

Hypotheses, Ideas

A Different Take on Humanities

F5: Refreshing Philology

Angelus Novus Looks to the Future.

On the Anti-Humanism which

Overcomes Nothingness

The Avant-Garde Artist: Between the All-Too-Human and the Inhuman.

Towards an Anthropological Aesthetics

From Global to Alter-Globalist

Art History

The Narrative Instinct.

The Anthropological Difference

in the Philological Framework 
173 ALEKSANDRA UBERTOWSKA

186

EWA DOMAŃSKA

211 JOANNAZYLINSKA

231

GRAŻYNA GAJEWSKA

248 ANNA BARCZ

270 SZYMON WRÓBEL

290 MONIKA BAKKE
Nature at Its Limits (Ecocide).

Subjectivity After the Catastrophe

Ecological Humanities

Bioethics Otherwise, or, How to Live with Machines, Humans, and Other Animals

On Erotically Marked Objects from the Perspective of Object Studies

Posthumanism and Its Animal Voices in Literature

Domesticating Animals:

A Description of a Certain Disturbance

"Between Us, Animals"

Emotional Ties Between Humans

and Other Animals 